\title{
Remdesivir for Treatment of COVID-19: Combination of Pulmonary and IV Administration May Offer Aditional Benefit
}

\author{
Duxin Sun ${ }^{1,2}$
}

Received 7 April 2020; accepted 13 April 2020; published online 26 May 2020

\begin{abstract}
Remdesivir is one of the most promising drugs to treat COVID-19 based on the following facts: remdesivir has a broad-spectrum antiviral mechanism of action; it demonstrated in vitro activity against SARS-CoV-2 and in vivo efficacy in animal models against the similar coronavirus MERS-CoV; its safety profile has been tested in Ebola patients and in compassionate use in COVID-19 patients. Currently, remdesivir is being investigated in ten randomized controlled trials against COVID-19. The dose regimen of remdesivir is an IV loading dose of $200 \mathrm{mg}$ on day 1 followed by daily IV maintenance doses of $100 \mathrm{mg}$ for 5-9 days. Based on our data analysis, however, remdesivir with IV administration alone is unlikely to achieve excellent clinical efficacy. This analysis is based on the following observations: plasma exposures of remdesivir and its active metabolite are unlikely to be correlated with its clinical efficacy; remdesivir and its active metabolites are unlikely to be adequate in the lung to kill the SARS-CoV-2 virus. Even if remdesivir demonstrates benefits in the current randomized controlled trials, its efficacy may be limited. We suggest that a combination of an IV and pulmonary delivery dose regimen should be studied immediately to realize a potentially more effective antiviral therapy against COVID-19.
\end{abstract}

KEY WORDS: clinical trials; COVID-19; drug metabolism; pharmacokinetics; pneumonia; pulmonary delivery; remdesivir; SARS-CoV-2.

\begin{abstract}
The pandemic of coronavirus disease 2019 (COVID-19) is not showing any signs of slowing down, and it may become a seasonal disease. Therefore, it is critical to develop therapies for COVID-19. Currently, remdesivir is being investigated against COVID-19 in ten randomized controlled trials. The dose regimen of remdesivir is an IV loading dose of $200 \mathrm{mg}$ on day 1 followed by daily IV maintenance doses of $100 \mathrm{mg}$ for 5-9 days (https://clinicaltrials.gov/ ). Several reports strongly suggest remdesivir would be efficacious against COVID-19. (a) Remdesivir has broad-spectrum of antiviral activity by inhibiting viral RNA synthesis [1]. (b) Remdesivir has demonstrated in vitro antiviral activity $\left(\mathrm{IC}_{50} 0.77 \mu \mathrm{M}\right)$ against SARS-CoV-2 [2]. (c) Studies of remdesivir have shown efficacy against other coronaviruses such as Middle East Respiratory Syndrome (MERS) virus MERS-CoV in vitro and in mice and monkeys [3-5]. (d) The current IV dose regimen of remdesivir was evaluated in a randomized controlled trial in human Ebola patients with some limited efficacy [6] and in a compassionate use in one COVID-19 patient [7].

During the time when this commentary was reviewed, an observational study of the compassionate use of remdesivir in
\end{abstract}

\footnotetext{
${ }^{1}$ Department of Pharmaceutical Sciences, College of Pharmacy, University of Michigan, Ann Arbor, Michigan 48109, USA.

${ }^{2}$ To whom correspondence should be addressed. (e-mail: duxins@umich.edu)
}

61 COVID-19 patients was published [8], showing clinical improvement in 36 of 53 patients $(68 \%)$ and an overall mortality of $13 \%$ in COVID-19 patients. This may be superior to the previous reports that demonstrated the overall mortality of $17-78 \%$ in severe COVID-19 cases [9-12]. However, authors have also outlined the limitations of this study [8], which include small sample size, no randomized control, exclusion of eight patients in the data analysis, and no pre-defined patient selection criteria and primary endpoints [13]. In addition, some of the patients were still on ventilator support at the time of data analysis [13].

These preliminary clinical findings do not provide clear evidence of remdesivir's efficacy against COVID-19. It is important to recognize that remdesivir was originally designed to treat Ebola, with excellent anti-Ebola virus activity in vitro and in animals [1]. Its $\mathrm{IC}_{50}(0.03-0.14 \mu \mathrm{M})$ against Ebola was 5- to 25-fold lower than the $\mathrm{IC}_{50}$ against SARS-CoV-2 [1]. Despite more potent antiviral activity, remdesivir only achieved some limited efficacy in Ebola patients [6]. Furthermore, studies of remdesivir demonstrated excellent efficacy against Middle East Respiratory Syndrome virus MERS-CoV in vitro, in mice $(25-50 \mathrm{mg} / \mathrm{kg}$ ) and in monkeys (3$10 \mathrm{mg} / \mathrm{kg}$ ) [3-5], which increases the hope for its efficacy against COVID-19. However, remdesivir's IC $_{50}$ against MERS-CoV was $0.03-0.34 \mu \mathrm{M}$, which is 2- to 25-fold lower than the $\mathrm{IC}_{50}$ for SARSCoV-2. Unfortunately, clinical data have not been reported evaluating remdesivir's efficacy in MERS human patients. 
Although remdesivir is still a promising treatment for COVID-19 patients, the current clinical studies with IV administration alone are unlikely to achieve excellent clinical efficacy. Based on our analysis, even if remdesivir demonstrates benefits in the randomized controlled trials, its efficacy will be limited. We suggest that nebulizer inhalation of remdesivir, in combination with IV administration, needs to be evaluated immediately to realize greater potential antiviral activity against COVID-19. In addition, dry powder inhalation of remdesivir, in combination with IV administration, should be considered a mid-term strategy for treatment of COVID-19 if COVID-19 becomes a seasonal disease. Furthermore, new modifications of remdesivir's structure and formulations should be investigated as a long-term strategy to improve its efficacy against COVID-19 in the future.

\section{PLASMA CONCENTRATIONS OF REMDESIVIR AND ITS ACTIVE METABOLITE ARE NOT LIKELY TO BE CORRELATED WITH ITS CLINICAL EFFICACY}

Remdesivir is a prodrug of nucleoside monophosphate (Nuc-MP) designed specifically to improve the cell permeability of Nuc-MP. The design of this prodrug bypasses the rate-limiting first phosphorylation step of the nucleoside (Nuc) (Fig. I) [1]. Therefore, remdesivir cannot be given by oral administration because the oral route will result in hydrolysis of the prodrug to Nuc-MP in the GI tract. This transformation will prevent absorption due to the charge of the phosphate group. In animals, remdesivir was IVadministered (10 mg/kg, equivalent to $100-200 \mathrm{mg}$ in human) $[14,15]$, and the remdesivir plasma concentrations decreased from $\sim 4$ to less than $\sim 1 \mu \mathrm{M}$ in $30 \mathrm{~min}$ (Table I) [1]. Remdesivir was rapidly hydrolyzed to the alanine metabolite followed by conversion to the nucleoside (Nuc). Nuc plasma concentration was $>0.3-1 \mu \mathrm{M}$ for $12-24 \mathrm{~h}$ (Table I). In contrast, Nuc-MP is charged and polar in plasma. Therefore, Nuc-MP can neither easily distribute into tissues nor penetrate cell membranes to enter cells. Distribution into cells is essential for antiviral activity. Therefore, plasma exposures of the prodrug remdesivir and its metabolites (i.e., alanine metabolite, nucleoside, and monophosphate) are not likely to be correlated with its clinical efficacy.

When remdesivir is administered intravenously, it distributes into tissues and blood cells through passive diffusion [1]. Once inside cells, remdesivir is converted into Nuc-MP by intracellular hydrolases, ultimately forming the active metabolite nucleoside triphosphate (Nuc-TP) intracellularly (Fig. I). Intracellular Nuc-TP is negatively charged and thus it is trapped inside cells with a half-life of 14-24 h (Table I). Therefore, Nuc-TP cannot be detected in plasma, but is only detected in blood cells such as peripheral blood mononuclear cells (PBMC) at highly accumulated concentrations (20$40 \mu \mathrm{M}$ ) [1] (Table I). The accumulation in PBMCs may be helpful to achieve antiviral activity against SARS-CoV-2 in these white blood cells. Since COVID-19 patients typically have lymphopenia, this suggests SARS-CoV-2 may infect lymphocytes [16]. If Nuc-TP accumulates in lymphocytes (not reported by Warren et al. [1]), an abundance of Nuc-TP in these cells may help to inhibit SARS-CoV-2. However, it is not known if the high intracellular accumulation of Nuc-TP in PBMCs is correlated with its clinical efficacy against COVID19 , nor if this intracellular distribution translates into the high intracellular concentration in the lung where SARS-CoV-2 infects.

\section{AT PRESENTLY ADOPTED IV DOSES, THE CONCENTRATIONS OF REMDESIVIR AND ITS ACTIVE METABOLITE ARE UNLIKELY TO BE ADEQUATE IN THE LUNG TO KILL THE SARS-COV-2 VIRUS}

SARS-CoV-2 infections cause mild, moderate, or severe pneumonia in COVID-19 patients. To achieve efficacy, we believe that remdesivir needs to be distributed into the lung and achieve adequate concentrations. Following IV dosing (100-200 mg), based on available data in human and animals [1, 4] (https://www.who.int/ebola/drc-2018/summaries-of-evidence-experimental-therapeutics.pdf?ua=1), and the following analysis, it is unlikely that remdesivir and its active metabolite nucleoside triphosphate (Nuc-TP) could reach adequate concentrations in the human lung to kill SARSCoV-2.

First, based on its physicochemical properties, instability in tissues, and pharmacokinetic properties, remdesivir is expected to have low tissue distribution and penetration, especially into the lung. In monkey studies, remdesivir was not detectable in the lung $[1,4]$, and the concentrations of its active metabolite nucleoside triphosphate (Nuc-TP) were only $0.8-1.5 \mu \mathrm{M}$ in the monkey lung following an IV dose of $10 \mathrm{mg} / \mathrm{kg}$ remdesivir (equivalent to a 100-200-mg dose in human) (Table II) [1, 4]. In carboxylesterase knockout mouse studies (Ces $1 c^{-/-}$prevents remdesivir hydrolysis), the Nuc-TP concentration in the mouse lung was $\sim 3 \mu \mathrm{M}$ following remdesivir IV 25-50 mg/kg (equivalent 140-280 $\mathrm{mg}$ in human) $[14,15]$; this result however may overestimate the drug distribution in the lung due to the lack of carboxylesterase in $\mathrm{Ces}_{1 c^{-1-}}$ mouse [4].

Second, the in vitro $\mathrm{IC}_{50}(0.77 \mu \mathrm{M})$ of remdesivir against SARS-CoV-2 in cell culture is a pseudo- $\mathrm{IC}_{50}$ since remdesivir is an inactive prodrug [2]. The true $\mathrm{IC}_{50}$ should be determined by the active form of the intracellular metabolite Nuc-TP, which would likely require significantly higher concentration in inhibiting the SARS-CoV-2. Due to its charge, Nuc-TP is trapped intracellularly and accumulates to concentrations at 50-300 $\mu \mathrm{M}$ when $1 \mu \mathrm{M}$ remdesivir was incubated with a variety of human and monkey cells (PBMC, monocytes, HeLa, macrophage, and HUVEC) (Table III) [1]. Therefore, a pseudo- $\mathrm{IC}_{50}$ of $0.77 \mu \mathrm{M}$ of prodrug remdesivir in cell culture would require a projected $\mathrm{IC}_{50}$ of $38-231 \mu \mathrm{M}$ of intracellular Nuc-TP in inhibiting the SARS-CoV-2 in the same cells [2]. In another study with 2B4 cells, the intracellular Nuc-TP accumulation was more than 3 -fold compared with extracellular remdesivir [4]. Therefore, an $\mathrm{IC}_{50}$ of $0.77 \mu \mathrm{M}$ of remdesivir in the cell culture would require an $\mathrm{IC}_{50}$ of $2.31 \mu \mathrm{M}$ of intracellular Nuc-TP. However, the calculation of intracellular concentration is not well defined since different laboratories may use different cellular volumes, cell numbers, or protein concentrations to normalize the intracellular concentration. On average, it is reasonable to assume that the intracellular Nuc-TP accumulates more than 10-fold compared with extracellular remdesivir because of intracellular trapping. Therefore, the in vitro pseudo- $\mathrm{IC}_{50}(0.77 \mu \mathrm{M})$ and $\mathrm{IC}_{90}(1.76 \mu \mathrm{M})$ of remdesivir [2] would require the true 

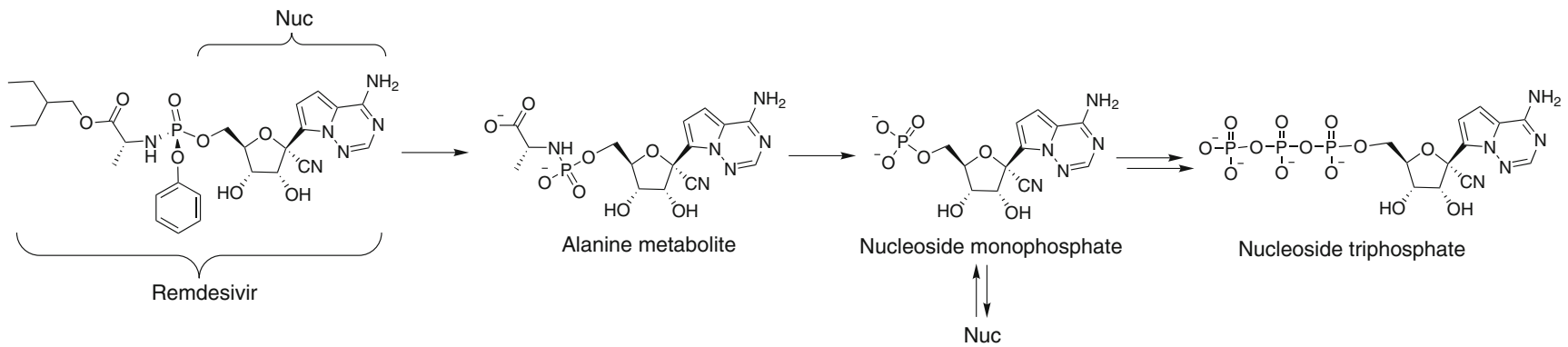

Fig. I. Structure of remdesivir and the metabolic conversions to the active metabolite nucleoside triphosphate (Nuc-TP) [1]

$\mathrm{IC}_{50}(>7.7 \mu \mathrm{M})$ and $\mathrm{IC}_{90}(>17.6 \mu \mathrm{M})$ of intracellular Nuc-TP to inhibit SARS-CoV-2 in cell culture (Table II).

Third, the current IV dose regimen (100-200 mg) in humans is unlikely to achieve detectable levels of remdesivir and an effective intracellular Nuc-TP concentrations in the lung $\left(\mathrm{IC}_{50}>7.7 \mu \mathrm{M}, \mathrm{IC}_{90}>17.6 \mu \mathrm{M}\right)$ to kill SARS-CoV-2. In human studies of Ebola patients, IV infusion of remdesivir (75 mg, 30-min infusion) achieved a plasma AUC of remdesivir of $1254 \mathrm{~h} * \mathrm{ng} / \mathrm{ml}$ (https://www.who.int/ebola/drc2018 / s u m maries - of - evidence - ex perimentaltherapeutics.pdf?ua=1) with a half-life of $1 \mathrm{~h}$. Therefore, plasma remdesivir would be undetectable after $8 \mathrm{~h}$ (with $\mathrm{T}_{1 / 2}$ $<1 \mathrm{~h}$ ), which is similar to the studies in monkeys [1]. It is reasonable to assume this AUC was mainly contributed by the AUC from 0 to $8 \mathrm{~h}$. Therefore, the average remdesivir plasma concentration may be estimated at $<0.25-1 \mu \mathrm{M}$ from 1 to $8 \mathrm{~h}(\mathrm{AUC} / 8 \mathrm{~h})$. The same IV infusion dose $(75 \mathrm{mg}, 30$ min infusion) generated an AUC of Nuc-TP in human PBMCs of $394 \mathrm{~h} * \mathrm{ng} / \mathrm{ml}$, which is significantly lower than that in PBMCs of monkeys (IV $10 \mathrm{mg} / \mathrm{kg}$ ) (https://www.who.int/ ebola/drc-2018/summaries-of-evidence-experimentaltherapeutics.pdf?ua=1). Nuc-TP showed a 3.46-fold accumulation ratio in human PBMCs compared with remdesivir (https://www.who.int/ebola/drc-2018/summaries-of-evidenceexperimental-therapeutics.pdf?ua=1). In monkey studies (IV $10 \mathrm{mg} / \mathrm{kg}$, equivalent to $100-200 \mathrm{mg}$ in humans), remdesivir plasma concentrations was $0.5-4 \mu \mathrm{M}$ from 10 to $30 \mathrm{~min}$, and Nuc-TP concentrations in monkey PBMCs was 20-40 $\mu \mathrm{M}$. However, remdesivir was not detectable and Nuc-TP concentration was only $0.8-1.5 \mu \mathrm{M}$ in the monkey lung tissues after remdesivir IV $10-\mathrm{mg} / \mathrm{kg}$ dose [1]. These pharmacokinetic comparisons suggest that the exposure of remdesivir and its active metabolite in human plasma, PBMCs, and the lung after IV infusion in human (75 $\mathrm{mg}$ over $30 \mathrm{~min}$ ) would be lower than or at most similar to that in monkeys (IV
$10 \mathrm{mg} / \mathrm{kg}$ ). Therefore, remdesivir is unlikely to be detectable in the human lung tissues. Assuming similar distribution and accumulation ratios of remdesivir and Nuc-TP in the lung between humans and monkeys, an optimistic estimation of Nuc-TP in the human lung tissues is 2 to 3 -fold higher at a steady state than that observed in the monkey lung tissues [1]. This suggests that an IV dose of $200 \mathrm{mg}$ remdesivir in a human may only achieve a suboptimal concentration of active form of Nuc-TP of $<2-5 \mu \mathrm{M}$ in the human lung tissues (Table III). Given that the intracellular volume $(0.541)$ is $46 \%$ of the total volume of the lung (1.17 1) [17], the intracellular concentration of Nuc-TP in the human lung may be only at 4-10 $\mu \mathrm{M}$ (Table III), which may be below the estimated intracellular $\mathrm{IC}_{50}$ and $\mathrm{IC}_{90}$ of Nuc-TP. Unfortunately, systemic adverse effects such as hepatotoxicity preclude escalation of the remdesivir dose to more than $200 \mathrm{mg}$ /day.

\section{PULMONARY DELIVERY OF REMDESIVIR NEEDS TO BE INVESTIGATED TO IMPROVE ITS CLINICAL EFFICACY AGAINST COVID-19}

Direct pulmonary delivery of remdesivir may provide higher lung concentrations of remdesivir and Nuc-TP as well as reduce the systemic toxicity in COVID-19 patients. To reach an intracellular Nuc-TP concentration of $17.6 \mu \mathrm{M}$ $\left(\mathrm{IC}_{90}\right)$ in the human lungs, the total amount of remdesivir to be delivered into the lung is projected to be approximately $10.5 \mathrm{mg}(17.6 \mu \mathrm{M} \times 0.541 \div 55 \% \times 603 \mathrm{~g} / \mathrm{mol})$, where $0.541 \mathrm{is}$ the total intracellular fluid volume $(46 \%)$ of human lung volume [17], and $55 \%$ of remdesivir in human cells was converted into Nuc-TP [1]. If we assume that only $20 \%$ of the dose is delivered into the lung while the other $80 \%$ of the remdesivir dose is lost in the oropharynx, device, and breath exhalation [18], the projected daily inhalation dose would be $52.5 \mathrm{mg}$ (Table IV).

Table I. Drug and Metabolite Concentrations in Plasma And PBMCs 2-24 h After an IV 10-mg/kg Dose in Monkey [1]

\begin{tabular}{llllll}
\hline $\begin{array}{l}\text { Remdesivir } \\
\text { (inactive) plasma }\end{array}$ & $\begin{array}{l}\text { Alanine metabolite } \\
\text { (inactive) plasma }\end{array}$ & $\begin{array}{l}\text { Nucleoside } \\
\text { (Nuc) (active) plasma }\end{array}$ & $\begin{array}{l}\text { Nucleoside triphosphate } \\
\text { (Nuc-TP) (active) plasma }\end{array}$ & $\begin{array}{l}\text { Nucleoside triphosphate } \\
\text { (Nuc-TP) (active) PBMC }\end{array}$ \\
\hline $0.5 \mathrm{~h}$ & $\sim 1 \mu \mathrm{M}$ & $\sim 2 \mu \mathrm{M}$ & $\sim 1 \mu \mathrm{M}$ & ND \\
$2 \mathrm{~h}$ & $<0.1 \mu \mathrm{M}$ & $<0.5 \mu \mathrm{M}$ & $\sim 1 \mu \mathrm{M}$ & $30-40 \mu \mathrm{M}$ \\
$8 \mathrm{~h}$ & $\mathrm{ND}$ & $<0.2 \mu \mathrm{M}$ & $\sim 0.4 \mu \mathrm{M}$ & $\mathrm{ND}$ & $20-30 \mu \mathrm{M}$ \\
$24 \mathrm{~h}$ & $\mathrm{ND}$ & $\mathrm{ND}$ & $<0.2 \mu \mathrm{M}$ & $\mathrm{ND}$ & $20-30 \mu \mathrm{M}$ \\
\hline
\end{tabular}


Table II. Extracellular and Intracellular Concentrations When Remdesivir $(1 \mu \mathrm{M})$ Was Incubated with Various Cells Compared with the IC 50 and $\mathrm{IC}_{90}$ Against SARS-CoV-2 [2]

\begin{tabular}{lllll}
\hline & Remdesivir & Alanine metabolite & Nucleoside (Nuc) & Nucleoside triphosphate (Nuc-TP) \\
\hline $\mathrm{IC}_{50}$ & $0.77 \mu \mathrm{M}$ & $\mathrm{ND}$ & $\mathrm{ND}$ & $\sim 7.7 \mu \mathrm{M}$ (estimated) \\
$\mathrm{IC}_{90}$ & $1.76 \mu \mathrm{M}$ & $\mathrm{ND}$ & $\mathrm{ND}$ & $\sim 17.6 \mu \mathrm{M}$ (estimated) \\
$\begin{array}{l}\text { Concentration in cell } \\
\quad \text { culture medium }\end{array}$ & $1 \mu \mathrm{M}$ & $\mathrm{ND}$ & $\mathrm{ND}$ & $\mathrm{ND}$ \\
$\begin{array}{l}\text { Intracellular concentration } \\
\text { n }\end{array}$ & $\mathrm{ND}$ & $1-70 \mu \mathrm{M}$ & $5-50 \mu \mathrm{M}$ & $50-300 \mu \mathrm{M}$ \\
\hline
\end{tabular}

ND, not determined

However, this inhalation dose estimation is based on theoretical calculation with uncertainty, which only serves as a general guideline. Since the inhalation dose is neither tested in animal models nor in humans, the dose selection needs to be discussed and approved by the regulatory agencies for human trials.

\section{Nebulizer Inhalation of Remdesivir should Be Investigated Immediately in COVID-19 Patients}

Nebulizer inhalation of remdesivir $50 \mathrm{mg}$ for $30 \mathrm{~min}$ is the easiest and fastest method of direct pulmonary administration. This regimen can be investigated using the current lyophilized formulation being used in the clinical trials of COVID-19 patients within days after regulatory approval (Table V). It is recommended that the duration of nebulizer inhalation of $50 \mathrm{mg}$ remdesivir should not be more than $1-2 \mathrm{~h}$, since remdesivir is not stable in aqueous solution $\left(\mathrm{T}_{1 / 2}<1-2 \mathrm{~h}\right)$ [19], and with longer inhalation periods, the drug would be hydrolyzed into nucleoside monophosphate (Nuc-MP) that cannot enter lung cells for its antiviral activity (Table V).

In addition, the nebulizer inhalation should be investigated in COVID-19 patients with mild pneumonia symptoms for the following reasons. First, COVID-19 patients with mild symptoms can self-administer nebulized remdesivir to minimize the risk to healthcare professionals due to aerosol generation. Second, nebulizer inhalation would be difficult to be administered in COVID-19 patients with ventilators. Third, the antiviral drug should be given to patients as early as possible [20,21], since it may not have much benefit for COVID-19 patients with severe pneumonia whose lung function may have been severely damaged.
However, we strongly suggest the nebulizer inhalation of remdesivir needs to be discussed and approved by the regulatory agencies to determine a correct dose and an appropriate formulation for this change in route of administration. Nebulizer inhalation may have variable delivery efficiency to the lung, which will affect the inhalation dose calculation. In addition, the current lyophilized formulation (with beta-cyclodextrin) as an inhalation dosage form has not been tested in animal models nor in humans.

\section{Dry Powder Inhalation of Remdesivir Needs to Be Evaluated as a Med-Term Strategy Against COVID-19}

If COVID-19 becomes a seasonal disease, a dry powder for inhalation could be developed for use as a mid-term strategy. A dry powder formulation of remdesivir could potentially be manufactured containing $2.5 \mu \mathrm{m}$ remdesivir crystalline form mixed with differently sized particles of lactose $(15$ to $200 \mu \mathrm{m})$. The prodrug remdesivir is anticipated to be stable enough in the alveolar space of the lung for 0.5$1 \mathrm{~h}$, which may be an adequate amount of time for it to diffuse into lung cells for its activity against SARS-CoV-2. Dry powder inhalation would be convenient and would also reduce the risk of spreading the virus to healthcare professionals by minimizing the aerosolization of lung secretions. However, a dry powder inhalation product would need a substantial development effort, including formulation research, manufacturing, scale up, and regulatory approvals. However, if pulmonary delivery is demonstrated to be safe and effective, this approach would be ideal for the treatment of COVID-19 patients in an outpatient setting, especially if COVID-19 becomes a recurrent seasonal disease.

Table III. Concentrations of Remdesivir and Its Active Metabolite in Monkey Lung Following an IV 10-mg/kg Dose [1] and Predicted Concentration in the Human Lung After an IV 200-mg Dose

\begin{tabular}{|c|c|c|c|c|c|c|c|c|}
\hline & \multicolumn{2}{|l|}{$2 \mathrm{~h}$} & \multicolumn{2}{|l|}{$24 \mathrm{~h}$} & \multirow{2}{*}{$\begin{array}{l}\text { Human } \\
\text { lung tissue }\end{array}$} & \multirow{2}{*}{$\begin{array}{l}\text { Human } \\
\text { lung intracellular }\end{array}$} & \multirow[t]{2}{*}{$\mathrm{IC}_{50}$} & \multirow[t]{2}{*}{$\mathrm{IC}_{90}$} \\
\hline & $\begin{array}{l}\text { Monkey } \\
\text { lung tissue }\end{array}$ & $\begin{array}{l}\text { Monkey } \\
\text { lung intracellular }\end{array}$ & $\begin{array}{l}\text { Monkey } \\
\text { lung tissue }\end{array}$ & $\begin{array}{l}\text { Monkey } \\
\text { lung intracellular }\end{array}$ & & & & \\
\hline Remdesivir & ND & ND & ND & ND & ND & ND & $0.77 \mu \mathrm{M}$ & $1.76 \mu \mathrm{M}$ \\
\hline Nuc-TP & $1.5 \mu \mathrm{M}$ & $\begin{array}{l}3.3 \\
\mu \mathrm{M} \text { (estimate) }\end{array}$ & $0.8 \mu \mathrm{M}$ & $\begin{array}{l}\sim 1.7 \\
\mu \mathrm{M}(\text { estimate })\end{array}$ & $\begin{array}{l}\sim 2-5 \\
\mu \mathrm{M} \text { (estimate) }\end{array}$ & $\begin{array}{l}\sim 4-10 \\
\mu \mathrm{M} \text { (estimate) }\end{array}$ & $\begin{array}{l}7.7 \\
\mu \mathrm{M} \text { (estimate) }\end{array}$ & $\begin{array}{l}17.6 \\
\mu \mathrm{M} \text { (estimate) }\end{array}$ \\
\hline
\end{tabular}


Table IV. Projected Inhalation Dose of Remdesivir

\begin{tabular}{|c|c|c|c|c|c|c|c|}
\hline $\begin{array}{l}\text { Required } \\
\text { intracellular } \mathrm{IC}_{90} \text { of } \\
\text { Nuc-TP in the lung }\end{array}$ & $\begin{array}{l}\text { Percentage } \\
\text { of remdesivir } \\
\text { metabolized into } \\
\text { Nuc-TP }(\%)\end{array}$ & $\begin{array}{l}\text { Molecular } \\
\text { weight of } \\
\text { remdesivir }\end{array}$ & $\begin{array}{l}\text { Intracellular } \\
\text { volume of the } \\
\text { human lung }\end{array}$ & $\begin{array}{l}\text { Total } \\
\text { volume of the } \\
\text { human lung }\end{array}$ & $\begin{array}{l}\text { Required dose } \\
\text { of remdesivir to } \\
\text { reach the lung }\end{array}$ & $\begin{array}{l}\text { Delivery } \\
\text { efficiency by } \\
\text { inhalation }(\%)\end{array}$ & $\begin{array}{l}\text { Total dose } \\
\text { required for } \\
\text { inhalation }\end{array}$ \\
\hline $17.6 \mu \mathrm{M}$ & 55 & 603 & 0.541 & 1.171 & $10.5 \mathrm{mg}$ & 20 & $52.5 \mathrm{mg}$ \\
\hline
\end{tabular}

Nuc-TP, nucleoside triphosphate

Modifications of Remdesivir Structure and Formulation Can Be a Long-Term Strategy Against COVID-19 in the Future

Remdesivir is one of the most promising drugs for treatment of COVID-19, but its efficacy may be limited by its poor physicochemical properties and poor tissue distribution/ penetration in the target organs (lung, spleen, lymph nodes, blood vessels, and others). Two approaches can be applied to improve these properties. One strategy is to modify the prodrug moiety without alteration of the active moiety (nucleoside monophosphate, Nuc-MP) [19]. The improved modified series of compounds would better balance the antiviral activity relative to enhance target tissue distribution. Another approach is to use nanoformulations of remdesivir or its modified analogs to enhance tissue targeting and efficacy [22,23]. Ideally, the modified compounds or formulations could be used either for IV administration and/or pulmonary delivery using a nano-inmicroparticle formulation. These approaches obviously require more effort to achieve an optimal form and thus should be considered a long-term strategy for future development in the midst of the current crisis.

\section{ADMINISTRATION OF REMDESIVIR IS STILL REQUIRED FOR ITS SYSTEMIC EFFICACY AGAINST COVID-19}

Most viruses specifically attack the lymphatic system and other organs causing tissue injury [16]. In addition to lung injury, lymphopenia and smaller spleen are often observed in COVID-19 patients. Therefore, in addition to inhibiting SARS-CoV-2 in the lung, the inhibition of the virus in lymphocytes, lymph nodes, the spleen, blood vessels, and other organs may still be required for adequate antiviral therapy. A previous report showed total radioactive ${ }^{14} \mathrm{C}$ remdesivir distribution after an IV $10-\mathrm{mg} / \mathrm{kg}$ dose in monkey [1]. Remdesivir and its metabolites were distributed into the testes, epididymis, eyes, and brain $(\sim 0.2$ to $2.3 \mu \mathrm{M})$ [1], while the concentration in the spleen, lymph nodes, and lymphocytes were not reported. It is reasonable to assume that the observed higher concentrations of nucleoside triphosphate (Nuc-TP) in PBMCs [1] may translate into an expectation of higher concentrations in lymphocytes and spleen. This may explain the clinical results of remdesivir that showed some limited efficacy in Ebola patients, where Nuc-TP would distribute into the spleen and lymph nodes to kill the Ebola virus in these organs [6]. Assuming that the SARS-CoV-2 virus may infect these lymphatic organs and other organs, an IV dose of remdesivir will undoubtedly still be required to achieve adequate exposure in the lymphatic organs and other organs for its systemic efficacy against COVID-19. However, if both inhalation and IV infusion doses are used, the IV dose may also need to be adjusted by consultation with regulatory agencies.

\section{LIMITATIONS}

Although we suggest that pulmonary delivery of remdesivir needs to be investigated in combination with the IV dose, several limitations are worth noting. (a) The Nuc-TP concentrations in the human lung are estimated with uncertainty. No technology is available to directly measure the drug concentration in human lungs. The best available pharmacokinetic data in human are the concentrations of remdesivir and its metabolites in plasma and PBMCs. The estimation of Nuc-TP concentration in the human lung tissues is based on the assumption that human and monkey lung cells have similar ability to uptake and accumulate remdesivir and NucTP. Different assumptions on the accumulation ratios between different species (ranging from 1 to 4-fold) may change the estimation of Nuc-TP concentration in the human lung tissues [1, 4]. Based on the pharmacokinetics and tissue concentrations of drugs in monkeys, pharmacokinetic models could be established to predict the drug concentration in human lung or other organs. However, most of the data needed for the development of these computational models are not available at this moment (such as drug metabolism

Table V. Dose Regimen of $50 \mathrm{mg}$ Remdesivir Using Nebulizer Inhalation

\begin{tabular}{|c|c|c|c|c|c|}
\hline $\begin{array}{l}\text { Inhalation } \\
\text { dose }\end{array}$ & $\begin{array}{l}\text { Solubility of current } \\
\text { clinical formulation [6] }\end{array}$ & $\begin{array}{l}\text { Inhalation } \\
\text { volume needed }\end{array}$ & $\begin{array}{l}\text { Inhalation time } \\
\text { needed }\end{array}$ & $\begin{array}{l}\text { Stability } \\
\text { in aqueous solution [19] }\end{array}$ & IV infusion dose, volume, time [6] \\
\hline $50 \mathrm{mg}$ & $\begin{array}{l}5 \mathrm{mg} / \mathrm{ml} \text { lyophilized } \\
\text { powder }\end{array}$ & $10 \mathrm{ml}$ & $\begin{array}{l}<30 \text { min (may need } \\
1-2 \text { times inhalation } \\
\text { for } 50-\mathrm{mg} \text { dose) }\end{array}$ & $\mathrm{T}_{1 / 2}=69 \mathrm{~min}$ & $\begin{array}{l}\text { Lyophilized } 100-\mathrm{mg} \text { dose is dissolved } \\
\text { in } 19 \mathrm{ml} \text { water, diluted in } 250 \mathrm{ml} \\
\text { saline, infused for } 30 \mathrm{~min}\end{array}$ \\
\hline
\end{tabular}


kinetics, protein binding, tissue distribution in various organs, and mass balance studies). Therefore, it will be challenging to accurately predict the drug concentrations in the human lung in the short term without additional studies. (b) Pulmonary delivery of remdesivir has its own challenges. For instance, the inhaled drug in the lung may not be evenly distributed throughout the lung. It is also difficult to estimate the intracellular concentrations of the drug and active metabolites in the lung. Furthermore, it is not clear what types of cells (alveolar macrophage, epithelial cells, and other cell types) should be targeted or what cells would preferentially uptake the drug for its efficacy against SARS-CoV-2 in the lung. Finally, the risk/benefit profile is not known for pulmonary delivery in COVID-19 patients who may have damaged lung function. (c) It is not clear what types of COVID-19 patients (with mild, moderate, or severe pneumonia) should use pulmonary delivery. Finally, there is a paucity of established clinical endpoints that could be readily used to evaluate the safety and efficacy of pulmonary treatment in these COVID19 patients.

Despite these limitations, however, nebulizer inhalation of remdesivir, in combination with IV administration, should be investigated immediately in COVID-19 patients. It would be advantageous not to wait for a few more months to start a new clinical trial using pulmonary delivery after the completion of the current ten randomized controlled clinical trials, since COVID-19 patients suffer high mortality in the current COVID-19 pandemic crisis.

\section{ACKNOWLEDGMENTS}

The author wishes to thank Wei Gao, Hongxiang $\mathrm{Hu}$, Mady Traore, Yudong Song, and Bo Wen for the discussion of the concept and preparation of the manuscript. I thank Hayley Paholak, Manjunath Pai, Jamie Do, Joseph Burnett, and Nathan Truchan for their help in editing the manuscript, and the reviewers for their helpful suggestions.

\section{REFERENCES}

1. Warren TK, Jordan R, Lo MK, Ray AS, Mackman RL, Soloveva V, et al. Therapeutic efficacy of the small molecule GS-5734 against Ebola virus in rhesus monkeys. Nature. 2016;531:381-5.

2. Wang M, Cao R, Zhang L, Yang X, Liu J, Xu M, et al. Remdesivir and chloroquine effectively inhibit the recently emerged novel coronavirus $(2019-\mathrm{nCoV})$ in vitro. Cell research. 2020;30:269-71.

3. de Wit E, Feldmann F, Cronin J, Jordan R, Okumura A, Thomas T, et al. Prophylactic and therapeutic remdesivir (GS5734) treatment in the rhesus macaque model of MERS-CoV infection. Proceedings of the National Academy of Sciences of the United States of America. 2020;117:6771-6.

4. Sheahan TP, Sims AC. Broad-spectrum antiviral GS-5734 inhibits both epidemic and zoonotic coronaviruses. Science translational medicine. 2017;9:1-10.

5. Sheahan TP, Sims AC, Leist SR, Schafer A, Won J, Brown AJ, et al. Comparative therapeutic efficacy of remdesivir and combination lopinavir, ritonavir, and interferon beta against MERS-CoV. Nature communications. 2020;11:222.

6. Mulangu S, Dodd LE, Davey RT Jr, Tshiani Mbaya O, Proschan M, Mukadi D, et al. A Randomized, Controlled Trial of Ebola Virus Disease Therapeutics. The New England journal of medicine. 2019;381:2293-303.

7. Holshue ML, DeBolt C, Lindquist S, Lofy KH, Wiesman J, Bruce H, et al. First Case of 2019 Novel Coronavirus in the United States. The New England journal of medicine. 2020;382:929-36.

8. Grein J, Ohmagari N, Shin D, Diaz G, Asperges E, Castagna A, et al. Compassionate Use of Remdesivir for Patients with Severe Covid-19. The New England journal of medicine. 2020.

9. Cao B, Wang Y, Wen D, Liu W, Wang J, Fan G, et al. A Trial of Lopinavir-Ritonavir in Adults Hospitalized with Severe Covid19. The New England journal of medicine. 2020.

10. Arentz M, Yim E, Klaff L, Lokhandwala S, Riedo FX, Chong $\mathrm{M}$, et al. Characteristics and Outcomes of 21 Critically Ill Patients With COVID-19 in Washington State. JAMA. 2020.

11. Zhou F, Yu T, Du R, Fan G, Liu Y, Liu Z, et al. Clinical course and risk factors for mortality of adult inpatients with COVID-19 in Wuhan, China: a retrospective cohort study. Lancet. 2020;395:1054-62.

12. Bhatraju PK, Ghassemieh BJ, Nichols M, Kim R, Jerome KR, Nalla AK, et al. Covid-19 in Critically Ill Patients in the Seattle Region - Case Series. The New England journal of medicine. 2020.

13. Farkas, J. https://emcrit.org/pulmcrit/pulmcrit-eleven-reasonsthe-nejm-paper-on-remdesivir-reveals-nothing/.

14. https://www.fda.gov/news-events/press-announcements/fda-approves-new-antibacterial-drug-treat-serious-lung-disease-usingnovel-pathway-spur-innovation. (acessed: 03.30.2020)

15. Zou P, Yu Y, Zheng N, Yang Y, Paholak HJ, Yu LX, et al. Applications of human pharmacokinetic prediction in first-inhuman dose estimation. The AAPS journal. 2012;14:262-81.

16. Yishan Zheng ZH, Yin G, Zhang X, Ye W, Hu Z, Hu C, et al. Comparative study of the lymphocyte change between COVID19 and non-COVID-19 pneumonia cases suggesting uncontrolled inflammation might not be the main reason of tissue injury. medRxiv. 2020. https://doi.org/10.1101/ 2020.02.19.20024885.

17. Davies B, M. T. Physiological parameters in laboratory animals and humans. Pharmaceutical research. 1993;10.

18. Newman SP, Busse WW. Evolution of dry powder inhaler design, formulation, and performance. Respir Med. 2002;96:293304.

19. Siegel D, Hui HC, Doerffler E, Clarke MO, Chun K, Zhang L, et al. Discovery and Synthesis of a Phosphoramidate Prodrug of a Pyrrolo[2,1-f][triazin-4-amino] Adenine C-Nucleoside (GS5734) for the Treatment of Ebola and Emerging Viruses. Journal of Medicinal Chemistry. 2017;60:1648-61.

20. Knight V, McClung HW, Wilson SZ, Waters BK, Quarles JM, Cameron RW, et al. Ribavirin small-particle aerosol treatment of influenza. Lancet. 1981;2:945-9.

21. Rodriguez WJ, Kim HW, Brandt CD, Fink RJ, Getson PR, Arrobio $\mathrm{J}$, et al. Aerosolized ribavirin in the treatment of patients with respiratory syncytial virus disease. Pediatr Infect Dis J. 1987;6:159-63.

22. Li F, Zhang H, He M, Liao J, Chen N, Li Y, et al. Different Nanoformulations Alter the Tissue Distribution of Paclitaxel, Which Aligns with Reported Distinct Efficacy and Safety Profiles. Molecular pharmaceutics. 2018;15:4505-16.

23. Luo R, Li Y, He M, Zhang H, Yuan H, Johnson M, et al. Distinct biodistribution of doxorubicin and the altered dispositions mediated by different liposomal formulations. International journal of pharmaceutics. 2017;519:1-10.

Publisher's Note Springer Nature remains neutral with regard to jurisdictional claims in published maps and institutional affiliations. 